\title{
Prospek Pengembangan Usaha Keripik Pisang di Bandarlampung
}

\author{
Prospect for Business Development of Banana Chips in Bandarlampung
}

\section{Marlinda Apriyani ${ }^{1 *}$, Hartisari Hardjomidjojo ${ }^{2 \sharp}$, dan Darwin Kadarisman ${ }^{3 *}$}

${ }^{1}$ Politeknik Negeri Lampung, Bandarlampung

Jl. Teuku Umar Gg. Seroja No. 5 RT.026 Kelurahan Surabaya Kec. Kedaton Bandar Lampung 35148 ${ }^{2}$ Departemen Teknologi Industri Pertanian, Fakultas Teknologi Pertanian Institut Pertanian Bogor ${ }^{3}$ Departemen Ilmu dan Teknologi Pangan, Fakultas Teknologi Pertanian Institut Pertanian Bogor \#Jl. Kamper Kampus IPB Darmaga, Bogor 16680

\begin{abstract}
ABSTRAK
Penelitian ini dilakukan untuk merumuskan skenario yang mungkin di masa depan (prospektif strategik). Skenario ini didasarkan pada kondisi yang mungkin terjadi di masa depan berdasarkan pada faktor-faktor kunci yang mempengaruhi perkembangan industri keripik pisang di Bandarlampung. Penelitian ini bertujuan untuk: (1) mengidentifikasi faktor-faktor yang memengaruhi perkembangan Usaha Kecil Menengah (UKM) keripik pisang, (2) menentukan perumusan strategi pengembangan UKM keripik pisang, dan (3) menentukan rekomendasi operasional untuk pengembangan dari UKM keripik pisang di Bandarlampung. Alat analisis yang digunakan adalah Analisis Prospektif untuk memprediksi kemungkinan yang terjadi di masa depan, mempersiapkan langkah strategik yang perlu dilakukan, dan melihat apakah diperlukan perubahan di masa depan. Hasil penelitian menunjukkan bahwa faktor penentu keberhasilan pengembangan usaha keripik pisang untuk meningkatkan pangsa pasar dan menjadi produk unggulan di Bandarlampung adalah: (1) kemampuan teknis, (2) keterampilan manajerial, (3) akses terhadap informasi, (4) proses produksi, dan (5) ketersediaan bahan baku. Perumusan strategi pengembangan usaha dilakukan dengan menggabungkan hasil analisis stakeholder dan analisis prospektif untuk menghasilkan skenario optimis dalam pengembangan keripik pisang di Bandarlampung. Rekomendasi operasional yang dihasilkan untuk pengembangan keripik pisang di Bandarlampung adalah: (1) meningkatkan kemampuan teknis pengusaha, (2) meningkatkan keterampilan manajerial, (3) peningkatan akses terhadap informasi, (4) proses produksi yang lebih modern, dan (5) meningkatkan ketersediaan bahan baku.
\end{abstract}

Kata kunci: prospek pengembangan, keripik pisang, analisis prospektif

\section{ABSTRACK}

This study conducted to formulate a possible scenario in the future (prospective strategic). The scenario is based on conditions that may occur in the future toward on the key factors that influence the development of banana chips industry in Bandarlampung. This study aimed to: (1) identify the factors that influence the development of banana chips Small Medium Enterprises (SMEs) industry in Bandarlampung, and (2) determine the formulation of banana chips SME development strategy in Bandarlampung, and (3) determine the operational recommendations for the development of banana chips SMEs in Bandarlampung. The analysis tool is the Prospective Analysis to predict the possibilities that occur in the future and prepare a strategic action needs to be done and see if changes are needed in the future. The studied showed that the critical success factors of banana chips business development in order to increase market share and become a superior product in Bandarlampung are (1) technical capability, (2) managerial skills, (3) access to information, (4) the production process, and (5) availability of raw materials. Formulation of enterprise development strategies carried out by combining the results of stakeholder analysis and a prospective analysis, to generate an optimistic scenario for the development of banana chips in Bandarlampung. Operational recommendations for the development of banana chips

\footnotetext{
*) Korespondensi:

Jl. Teuku Umar Gg. Seroja No. 5 RT.026 Kelurahan Surabaya Kec. Kedaton Bandar Lampung 35148

e-mail: lindazein9483@gmail.com
} 
in Bandarlampung prepared using a prospective analysis: (1) increase the technical ability of entrepreneur, (2) increase the managerial skills, (3) increased access to information, (4) modern processes for production, and (5) increasing the availability of raw materials.

Key words: prospect for development, banana chips, prospective analysis

\section{PENDAHULUAN}

Provinsi Lampung mempunyai potensi yang cukup besar dalam pengembangan agroindustri, terutama untuk agroindustri dengan orientasi pasar antar daerah maupun ekspor. Provinsi Lampung memiliki potensi lahan pertaian yang cukup luas untuk kebutuhan bahan baku agroindustri.

Provinsi Lampung memiliki berbagai produk olahan pangan, di antaranya aneka keripik, produk olahan manggis, susu kacang, dodol tomat, emping, dan lain-lain. Dari berbagai hasil olahan tersebut, industri aneka keripik berkembang cukup pesat. Keripik pisang merupakan produk olahan yang cukup diminati masyarakat. Perkembangan industri keripik pisang ini didukung oleh produksi buah pisang di Provinsi Lampung. Data produksi buah pisang untuk Kabupaten/Kota di Provinsi Lampung Tahun 2005-2009 dapat dilihat pada Tabel 1.

Produksi pisang dari tahun ke tahun semakin meningkat, karena tanaman pisang merupakan salah satu komoditi unggulan Provinsi Lampung selain kopi dan lada. Umumnya pisang dipasarkan masih dalam bentuk pisang mentah. Namun mengingat sifatnya yang mudah busuk dan tidak tahan lama, perlu adanya upaya untuk mengolah pisang menjadi produk lain, seperti keripik pisang.

Dinas Koperasi, Usaha Mikro Kecil Menengah (UMKM), Perindustrian dan Perdagangan Kota Bandarlampung mencatat sebanyak 8.862 UKM yang ada di Kota Bandarlampung sampai Desember 2011. Usaha Kecil Menengah (UKM) ini terdiri dari 2.035 UKM formal dan 6.827 UKM nonformal. UKM non formal keberadaannya tidak bisa dipastikan pada saat-saat tertentu karena bukan merupakan kegiatan pokok.

Pengembangan potensi UKM di Lampung pada sektor agribisnis cukup baik, terlihat dari usaha pemerintah daerah yang menjadikan beberapa daerah khususnya di Kotamadya Bandarlampung menjadi sentra produksi agribisnis. Salah satu contohnya adalah sentra keripik di Kelurahan Gunung Terang yang tergabung dalam Kelompok Usaha Bersama Telo Rejeki. Saat ini tercatat sebanyak 32 pengusaha keripik yang ada di sentra keripik tersebut.

Industri keripik di Bandarlampung potensial untuk dikembangkan. Hal ini terlihat dari semakin meningkatnya jumlah penjual dan produk yang ditawarkan, Tidak hanya terbatas pada keripik pisang, namun para pengusaha juga menawarkan keripik singkong, talas, ubi jalar dan sukun. Perkembangan usaha keripik yang cukup nyata ini mendorong pengusaha keripik dan Pemerintah Kota Bandarlampung untuk terus meningkatkan pangsa pasar dan menjadikan keripik pisang sebagai salah satu produk unggulan Kota Bandarlampung. Hal ini didukung dengan jumlah produksi pisang yang semakin meningkat dan kebijakan Pemerintah Provinsi yang terus mendukung perkembangan UKM di Provinsi Lampung.

Keripik pisang diharapkan dapat menjadi salah satu produk unggulan Kota Bandarlampung dan terus meningkatkan pangsa pasar, tidak hanya terbatas pada penjualan domestik saja, tetapi diharapkan mampu menembus pasar ekspor. Salah satu upaya yang dapat dilakukan untuk menjawab permasalahan tersebut adalah dengan mencari dan menentukan faktor-faktor kunci yang menjadi penentu keberhasilan pengembangan usaha. Faktor-faktor kunci tersebut diharapkan mampu menjawab permasalahan yang ada pada industri keripik pisang di Bandarlampung.

Iklim kompetisi yang semakin tinggi memerlukan suatu formulasi strategi untuk dikembangkan pada sentra industri keripik di Bandar Lampung. Penelitian ini merumuskan formulasi strategi sesuai skenario yang mungkin terjadi di masa mendatang (prospective analysis). Skenario disusun berdasarkan keadaan yang mungkin terjadi di masa datang pada faktor kunci yang berpengaruh terhadap pengembangan industri keripik pisang di Bandarlampung.

Tujuan penelitian ini mengidentifikasi faktor-faktor yang memengaruhi pengembangan UKM keripik pisang, menentukan skenario strategi pengembangan UKM keripik pisang, dan menentukan implikasi operasional pengembangan UKM keripik pisang di Bandarlampung. 
Tabel 1. Produksi Buah Pisang menurut Kabupaten/Kota di Provinsi Lampung Tahun 2005 - 2009 (Kuintal)

\begin{tabular}{lrrrrr}
\hline \multicolumn{1}{c}{ Kabupaten/Kota } & $\mathbf{2 0 0 5}$ & $\mathbf{2 0 0 6}$ & $\mathbf{2 0 0 7}$ & $\mathbf{2 0 0 8}$ & $\mathbf{2 0 0 9}$ \\
\hline Kab. Lampung Barat & 33.664 & 41.048 & 260.045 & 101.057 & 93.771 \\
Kab. Tanggamus & 176.532 & 133.194 & 130.736 & 193.157 & 193.522 \\
Kab. Lampung Selatan & 3.915 .233 & 3.893 .278 & 4.433 .287 & 1.242 .020 & 2.325 .288 \\
Kab. Lampung Timur & 988.206 & 885.782 & 1.073 .534 & 1.235 .256 & 1.076 .758 \\
Kab. Lampung Tengah & 127.210 & 124.921 & 145.480 & 130.295 & 93.195 \\
Kab. Lampung Utara & 91.649 & 90.378 & 81.877 & 77.836 & 42.353 \\
Kab. Way Kanan & 102.601 & 113.975 & 179.207 & 233.276 & 75.643 \\
Kab. Tulang Bawang & 57.384 & 66.082 & 40.403 & 56.815 & 28.893 \\
Kab. Pesawaran & - & - & - & 3.135 .751 & 2.875 .845 \\
Kota Bandar Lampung & 4.961 & 6.915 & 6.125 & 16.954 & 9.246 \\
Kota Metro & 1.843 & 1.743 & 4.389 & 4.613 & 4.234 \\
\hline Jumlah & 5.499 .283 & 5.357 .316 & 6.355 .083 & 6.427 .030 & 6.818 .748 \\
\hline
\end{tabular}

Sumber: BPS, Lampung dalam Angka, 2010.

\section{METODOLOGI}

Penelitian ini dilaksanakan di Kelurahan Gunung Terang Kecamatan Tanjung Karang Barat Kotamadya Bandarlampung secara sengaja (purposive), dengan mempertimbangkan daerah ini sebagai sentra industri keripik di Bandarlampung. Data dikumpulkan dengan kuesioner yang dilakukan melalui wawancara oleh peneliti. Narasumber yang diwawancarai dalam penelitian ini tiga orang, terdiri dari:

1. Kepala Bidang Perindustrian Dinas Koperasi, UMKM, Perindustrian dan Perdagangan Kota Bandarlampung.

2. Pengusaha keripik yang juga merupakan Ketua Kelompok Usaha Bersama Telo Rejeki.

3. Pengusaha keripik yang juga merupakan Anggota Kelompok Usaha Bersama Telo Rejeki.

Ketiga orang responden ini dipilih karena memiliki pengetahuan baik dan pengalaman mumpuni mengenai topik yang akan diteliti, yaitu keripik pisang. Pengetahuan dan pengalaman pakar tersebut diharapkan memberikan informasi dengan baik, sehingga dapat menjawab tujuan penelitian.

\section{Pengolahan dan Analisis Data}

Metode yang digunakan adalah analisis deskriptif kualitatif dan kuantitatif. Metode pengolahan dan analisis data pada penelitian ini adalah Analisis Prospektif. Software yang digunakan adalah Microsoft Excell yang dimodifikasi dengan penghitungan analisis prospektif. Analisis prospektif digunakan untuk memprediksi kemungkinan-kemungkinan yang terjadi di masa depan. Analisis prospektif digunakan untuk mempersiapkan tindakan strategik yang perlu dilakukan dan melihat apakah perubahan diperlukan di masa depan (Hardjomidjojo, 2004).

Tahapan analisis prospektif menurut Bourgeois dan Jesus (2004) adalah:

1. Menentukan tujuan sistem yang dikaji secara spesifik dan dapat dimengerti oleh semua pakar yang akan diminta pendapatnya. Tujuan sistem yang dikaji adalah pengembangan industri keripik pisang di Bandarlampung untuk meningkatkan pangsa pasar dan menjadikan keripik pisang sebagai produk unggulan Kota Bandar Lampung.

2. Identifikasi faktor-faktor yang berpengaruh dalam pencapaian tujuan tersebut biasanya merupakan kebutuhan stakeholders sistem yang dikaji. Penelitian ini mengkaji faktorfaktor yang berpengaruh dalam pengembangan industri keripik pisang di Bandarlampung. Setelah diidentifikasi, faktor-faktor tersebut didefinisikan agar semua pakar memiliki persepsi yang sama, sehingga dapat menilai faktor-faktor tersebut sesuai dengan definisi faktor dan tujuan sistem.

3. Penilaian pengaruh langsung antar faktor. Semua faktor yang teridentifikasi dan terdefinisi akan dinilai pengaruh langsung antar faktor, berpedoman pada penilaian seperti dimuat dalam Tabel 2.

Tabel 2. Pedoman penilaian analisis prospektif

\begin{tabular}{cl}
\hline Skor & \multicolumn{1}{c}{ Pengaruh } \\
\hline 0 & Tidak ada pengaruh \\
1 & Berpengaruh kecil \\
2 & Berpengaruh sedang \\
3 & Berpengaruh sangat kuat \\
\hline
\end{tabular}

Hasil matriks gabungan dari pendapat pakar diolah dengan perangkat lunak analisis prospektif degan teknik statistik untuk meng- 
hitung pengaruh langsung global, ketergantungan global, kekuatan global, dan kekuatan global tertimbang. Hasil perhitungan divisualisasikan dalam diagram pengaruh dan ketergantungan antar faktor (Gambar 1).

4. Penyusunan keadaan yang mungkin terjadi (state) pada faktor. Keadaan bukan merupakan tingkatan atau ukuran suatu faktor (seperti besar, sedang, kecil, atau baik/buruk), tetapi merupakan deskripsi tentang situasi dari sebuah faktor. Pada penelitian ini skenario disusun berdasarkan faktor dominan pada kuadran I dan faktor penghubung (stakes) pada kuadran II.

5. Membangun dan memilih skenario. Skenario disusun berdasarkan kombinasi dari hubungan beberapa keadaan faktor secara timbal balik (mutual compatible) dari keadaan yang paling optimis sampai paling pesimis.

6. Analisis skenario dan penyusunan strategi. Berdasarkan skenario yang disusun pada tahap sebelumnya didiskusikan strategi yang perlu dilakukan bagi pencapaian skenario yang diinginkan ataupun menghindari skenario berdampak negatif pada sistem.

\section{HASIL DAN PEMBAHASAN}

\section{Identifikasi Faktor Kunci Pengembangan Usaha}

Upaya pengembangan usaha keripik pisang dengan analisis prospektif dilakukan dengan mengidentifikasi seluruh faktor yang memenga- ruhi pengembangan usaha di masa mendatang. Identifikasi faktor kunci pengembangan usaha didasarkan pada faktor-faktor yang berpengaruh terhadap pengembangan usaha keripik pisang di Kota Bandarlampung.

Menurut Hubeis (2009) terdapat tujuh faktor permasalahan usaha kecil dalam arti luas, yaitu: (1) kesulitan pemasaran, (2) keterbatasan finansial, (3) keterbatasan SDM, (4) masalah bahan baku, (5) keterbatasan teknologi, (6) managerial skill, dan (7) kemitraan. Berdasarkan hasil wawancara mendalam dengan para pakar, diperoleh 13 faktor-faktor yang berpengaruh terhadap pengembangan usaha keripik pisang di Kota Bandarlampung, mencakup: (1) kemampuan teknis, (2) kemampuan manajerial, (3) kemampuan permodalan, (4) ketersediaan bahan baku, (5) proses produksi, (6) kondisi peralatan, (7) pemasaran, (8) inovasi produk, (9) lokasi usaha, (10) promosi, (11) kemampuan manajemen keuangan, (12) kemampuan teknologi, dan (13) akses informasi.

Jika dibandingkan pendapat Hubeis (2009) dengan pendapat pakar di lapangan, ternyata kemitraan bukan merupakan faktor utama yang berpengaruh terhadap pengembangan usaha keripik pisang di Bandarlampung. Hal ini karena tidak semua pengusaha keripik melakukan kemitraan dengan pihak lain atau perusahaan lain yang lebih besar. Hanya beberapa pengusaha saja yang melakukan kerjasama dengan PTPN VII melalui Program Kemitraan Bina Lingkungan (PKBL) PTPN VII, hal ini menunjukkan kespesifikan usaha keripik pisang.

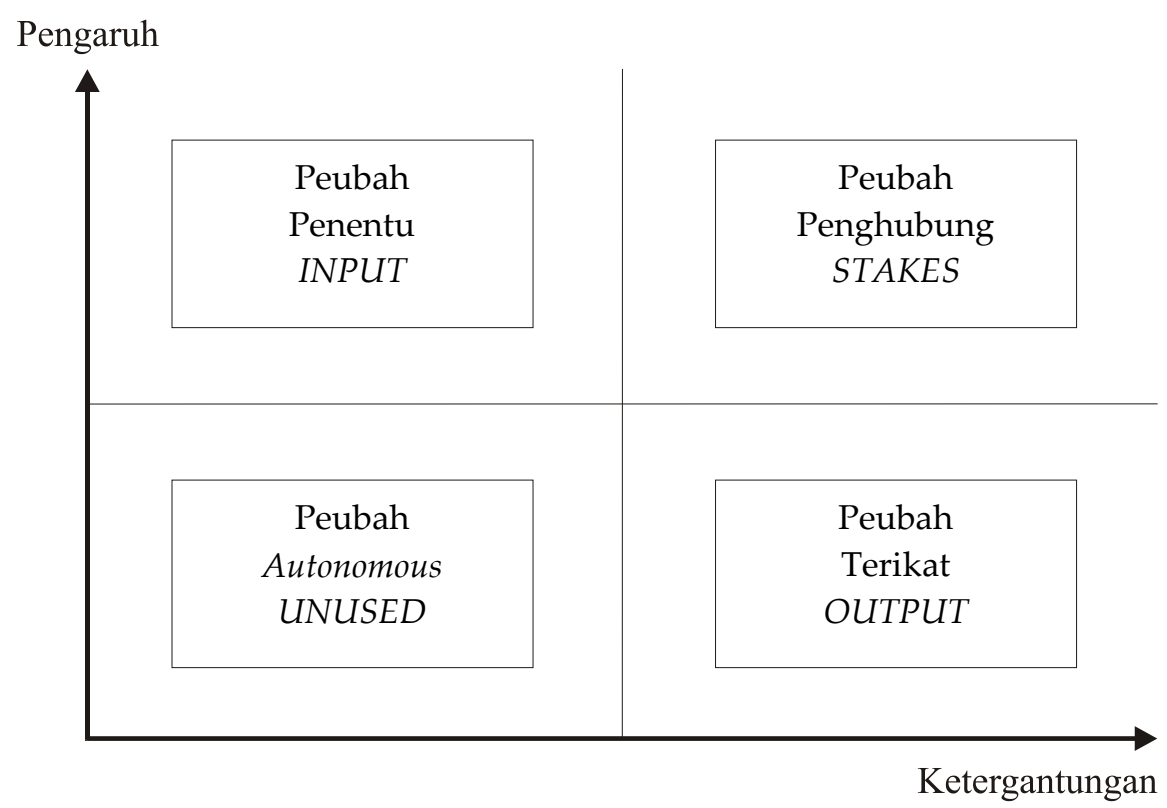

Gambar 1. Diagram pengaruh dan ketergantungan sistem (Bourgeios dan Jesus, 2004) 
Setelah teridentifikasi faktor-faktor yang memengaruhi pengembangan usaha keripik pisang tersebut, maka setiap faktor didefinisikan agar semua pakar mengerti dan memiliki persepsi yang sama mengenai faktor yang akan dinilai. Selain itu, definisi faktor juga dilakukan agar hasil penilaian faktor sesuai dengan definisi dan tujuan sistem. Definisi faktor-faktor tersebut diperoleh melalui wawancara dengan para pakar. Definisi faktor disesuaikan dengan kondisi yang ada di lapangan dan permasalahan yang terjadi. Pendefinisian ini dilakukan secara hati-hati, agar tidak terjadi kesalahan persepsi antara masingmasing pakar.

\section{Analisis Pengaruh Langsung Antar Faktor Pengembangan Usaha}

Definisi masing-masing faktor dijadikan sebagai acuan/pertimbangan untuk menilai pengaruh antar faktor. Penilaian dilakukan oleh tiga orang pakar yang mengetahui sistem pengelolaan usaha keripik pisang. Penilaian pengaruh langsung antar faktor oleh pakar diolah dengan perangkat lunak analisis prospektif yang divisualisasikan dalam diagram pengaruh dan ketergantungan faktor. Dari diagram pengaruh dan ketergantungan faktor, diperoleh faktorfaktor kunci yang paling berpengaruh pada pengembangan usaha keripik pisang di Bandarlampung (Gambar 2). Faktor-faktor tersebut nantinya digunakan untuk menyusun skenario-skena- rio pengembangan usaha keripik pisang di masa mendatang.

Faktor-faktor yang terdapat pada Kuadran I dan II merupakan faktor kunci yang sangat berpengaruh terhadap pengembangan usaha. Dari hasil analisis dapat disimpulkan bahwa terdapat lima faktor kunci yang memengaruhi pengembangan usaha keripik pisang di Bandarlampung, yaitu: (1) kemampuan teknis, (2) kemampuan manajerial, (3) akses informasi, (4) proses produksi, dan (5) ketersediaan bahan baku. Pengembangan usaha keripik pisang di Bandarlampung akan tercapai dengan proses produksi yang baik dan ketersediaan bahan baku yang cukup jumlah dan tepat waktu. Berdasarkan faktor-faktor kunci tersebut, selanjutnya akan diformulasikan skenario pengembangan usaha keripik pisang di Bandarlampung.

\section{Formulasi Strategi Pengembangan Usaha}

Skenario pengembangan usaha disusun berdasarkan faktor-faktor kunci yang berpengaruh pada pengembangan usaha keripik pisang di Kota Bandarlampung. Dari faktor-faktor kunci tersebut dideskripsikan berbagai keadaan (state) yang mungkin akan terjadi di masa mendatang. Dari kelima faktor kunci yang berpengaruh terhadap pengembangan usaha, selanjutnya dipilih keadaan yang mungkin terjadi di masa mendatang.

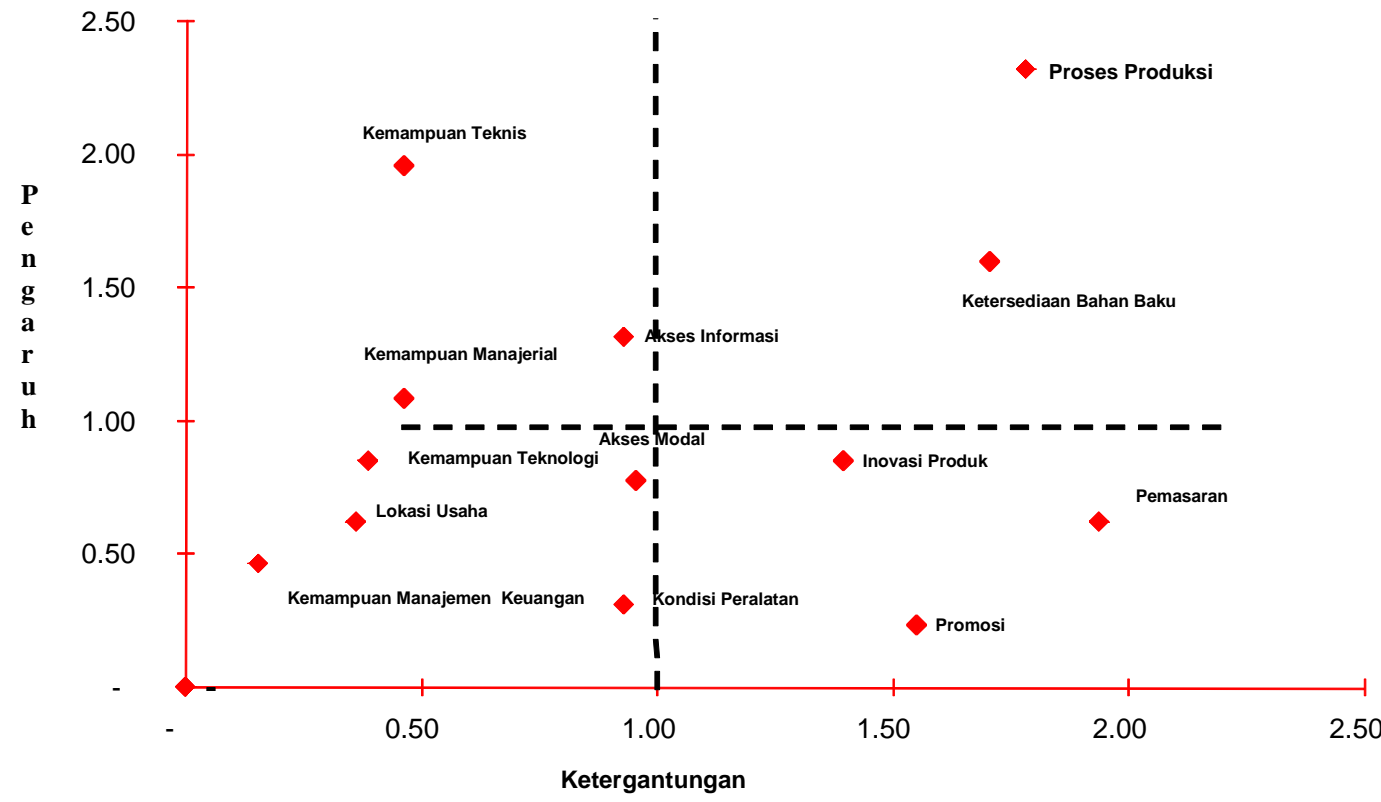

Gambar 2. Tingkat kepentingan faktor-faktor yang berpengaruh pada pengembangan UKM keripik pisang di Bandarlampung 
Menurut Hardjomidjojo (2002), penyusunan skenario dimaksudkan untuk memprediksi kemungkinan yang dapat terjadi pada faktor tersebut, yaitu apakah akan berkembang ke arah yang lebih baik dari sekarang, tetap, atau akan semakin buruk dari keadaan sekarang. Skenario disusun dalam rangka menghasilkan rekomendasi operasional untuk pengembangan usaha di masa depan. Pemetaan keadaan faktor penentu pengembangan industri keripik pisang di Bandarlampung dapat dilihat pada Tabel 3.

Berdasarkan hasil pemetaan pada Tabel 3 dapat disusun skenario pengembangan usaha keripik pisang di Bandarlampung. Kondisi sekarang (Baseline) merupakan kondisi awal untuk mencapai skenario optimis, yaitu 1B-2B-3B-4B-5B. Skenario pengembangan usaha keripik pisang di Bandarlampung dapat dilihat pada Tabel 4.

Berdasarkan skenario-skenario yang telah disusun, skenario optimis (skenario 3) merupakan skenario yang diharapkan terjadi. Demi mewujudkan skenario ini dibutuhkan dukungan yang besar dari berbagai pihak, seperti pengusaha keripik sendiri, Pemerintah Kota Bandarlampung dan pihak swasta.

Keripik pisang merupakan produk yang potensial untuk dikembangkan sehingga dapat menjadi salah satu produk unggulan. Produk unggulan merupakan produk potensial untuk dikembangkan dalam suatu wilayah dengan memanfaatkan sumber daya alam (SDA) dan sumber daya manusia (SDM) setempat, serta mendatangkan pendapatan bagi masyarakat maupun pemerintah. Dalam hal ini, produk unggulan merupakan hasil proses dari suatu kegiatan berupa barang atau jasa yang mempunyai keunggulan tersendiri dan dapat bersaing di pasar secara berkelanjutan. Selain itu mutu produk tetap dijaga dan dipertahankan, diantaranya melalui pemilihan bahan baku yang baik, penggunaan SOP yang seragam pada semua perajin, pelabelan dan pengemasan yang memenuhi kriteria, penyuluhan mengenai pengolahan dari Dinas terkait (Putri et al, 2012).

Tabel 3. Pemetaan keadaan faktor-faktor penentu pengembangan industri keripik pisang di Bandarlampung

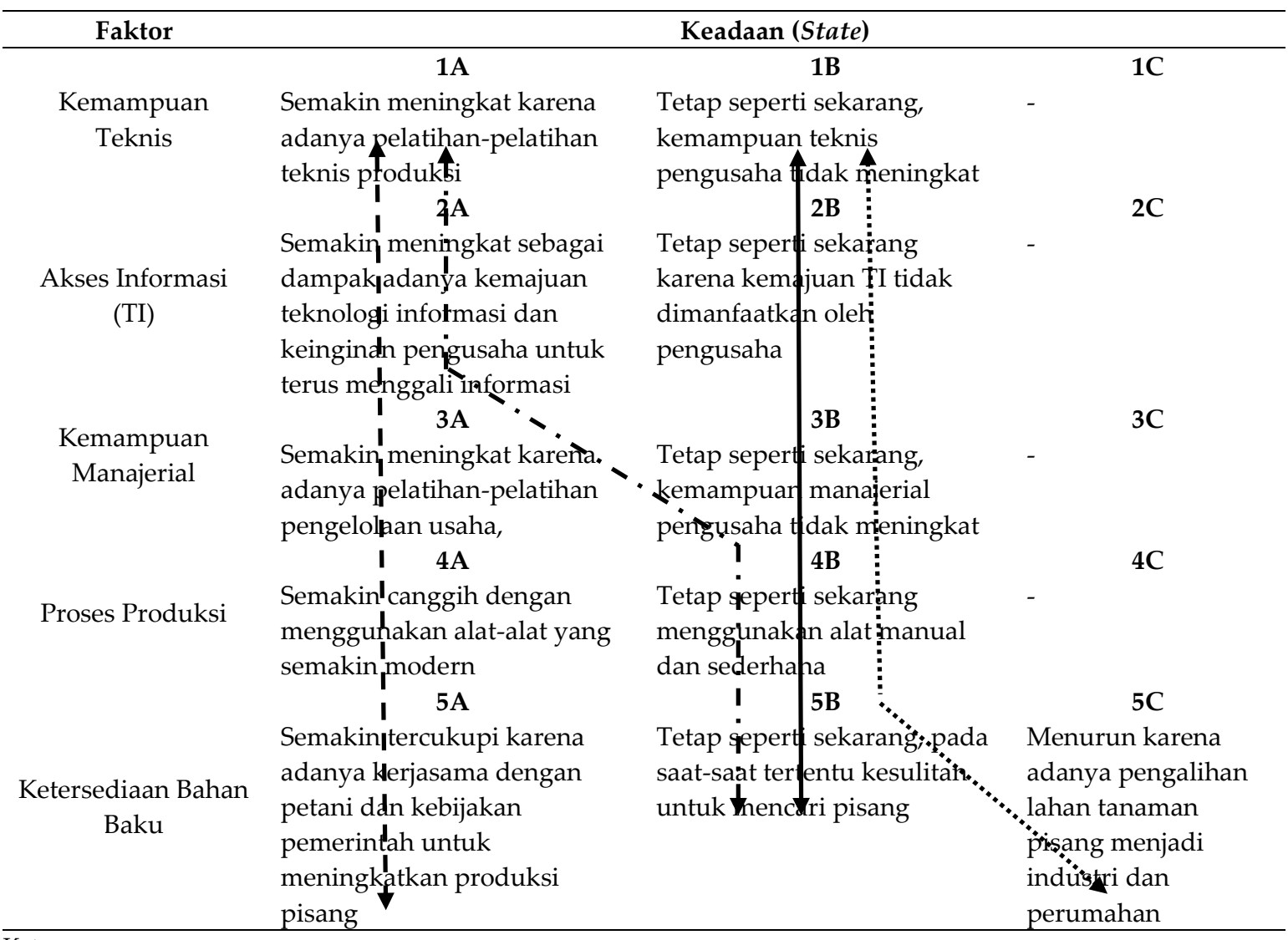

Keterangan:

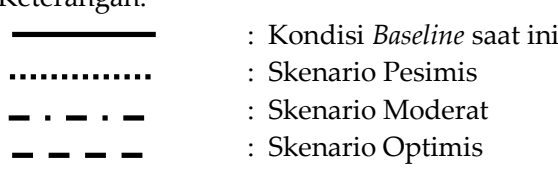


Tabel 4. Skenario pengembangan usaha keripik pisang di Bandarlampung

\begin{tabular}{ccc}
\hline \multicolumn{2}{c}{$\begin{array}{c}\text { Kondisi sekarang } \\
(\text { Baseline })\end{array}$} & $1 \mathrm{~B}-2 \mathrm{~B}-3 \mathrm{~B}-4 \mathrm{~B}-5 \mathrm{~B}$ \\
\hline No & Skenario & Keadaan \\
\hline 1 & Pesimis & $1 \mathrm{~B}-2 \mathrm{~B}-3 \mathrm{~B}-4 \mathrm{~B}-5 \mathrm{C}$ \\
2 & Moderat & $1 \mathrm{~A}-2 \mathrm{~A}-3 \mathrm{~B}-4 \mathrm{~B}-5 \mathrm{~B}$ \\
3 & Optimis & $1 \mathrm{~A}-2 \mathrm{~A}-3 \mathrm{~A}-4 \mathrm{~A}-5 \mathrm{~A}$ \\
\hline
\end{tabular}

Beberapa ciri produk unggulan telah dimiliki oleh usaha keripik pisang di Bandarlampung, yaitu (1) hampir seluruh bahan baku yang digunakan merupakan produk lokal, (2) penyerapan tenaga kerja untuk usaha ini semakin tinggi dengan semakin berkembangnya usaha, sehingga membutuhkan tenaga kerja semakin banyak, (3) pertumbuhan usaha keripik pisang semakin hari semakin meningkat, (4) kawasan sentra industri keripik di Bandarlampung berwawasan lingkungan, yaitu dilihat dari lingkungan usaha yang bersih dan tidak ada limbah yang berbahaya bagi masyarakat, serta (5) jangkauan pemasaran juga semakin diperluas sebagai salah satu usaha untuk meningkatkan pangsa pasar keripik pisang.

\section{Implikasi Operasional}

Implikasi operasional pengembangan usaha keripik pisang di Bandarlampung disusun berdasarkan skenario yang diharapkan terjadi, yaitu skenario optimis. Skenario optimis menjadi usaha keripik pisang dengan pangsa pasar yang luas dan menjadi salah satu produk unggulan Kota Bandarlampung. Skenario ini perlu didorong agar terjadi dengan memperhatikan faktor-faktor kunci/penentu yang sangat berpengaruh terhadap pengembangan usaha. Faktor-faktor tersebut meliputi kemampuan teknis, kemampuan manajerial, akses informasi, proses produksi dan ketersediaan bahan baku.

Kondisi optimis merupakan kondisi yang diharapkan terjadi. Tahapan-tahapan yang dapat dilakukan untuk mendorong kondisi optimis yaitu: (1) meningkatkan kemampuan teknis produksi pengusaha keripik dengan sering mengikuti pelatihan-pelatihan, (2) meningkatkan akses informasi, (3) meningkatkan kemampuan manajerial pengusaha keripik dengan mengikuti pelatihan di bidang manajerial seperti pelatihan pembukuan sederhana, (4) mendorong proses produksi untuk menggunakan alat yang lebih canggih dan modern, serta (5) mendorong bahan baku yang digunakan agar selalu tersedia cukup jumlah dan tepat waktu

\section{KESIMPULAN}

Faktor-faktor penentu keberhasilan pengembangan usaha keripik pisang meliputi kemampuan teknis, akses informasi, kemampuan manajerial, proses produksi dan ketersediaan bahan baku. Formulasi strategi pengembangan usaha dilakukan dengan menggabungkan hasil analisis stakeholders dan prospektif yang menghasilkan skenario optimis untuk pengembangan usaha keripik pisang di Bandarlampung. Implikasi operasional untuk pengembangan usaha keripik pisang di Bandarlampung disusun dengan analisis prospektif meliputi (1) peningkatan kemampuan teknis pengusaha, (2) peningkatan akses informasi, (3) peningkatan kemampuan manajerial pengusaha, (4) proses produksi yang lebih modern, dan (5) meningkatkan ketersediaan bahan baku.

\section{DAFTAR PUSTAKA}

BPS Provinsi Lampung. 2010. Lampung dalam Angka 2010. BPS Provinsi Lampung. Lampung.

Bourgeois, R., dan F. Jesus. 2004. Participatory Prospectiv Analysis; Exploring and Anticipating Challenges with Stakeholders. CAPSA Monograph No 46. United Nations.

Dinas Koperasi, Usaha Mikro Kecil Menengah (UMKM), Perindustrian dan Perdagangan Kota Bandar Lampung. 2011. Data Monitoring UKM 2011. Bandar Lampung.

Hardjomidjojo, H. 2002. Metode Analisis Prospektif. Departemen Teknologi Industri Pertanian Fakultas Pertanian Institut Pertanian Bogor, Bogor.

2004. Strategi Pengembangan UKM di Indonesia. Kumpulan Makalah dalam Simposium Analisis Sistem. Bandung.

Hubeis, M. 2009. Prospek Usaha Kecil dalam Wadah Inkubator Bisnis. Ghalia Indonesia, Bogor.

Putri, D.D., A. Mulyani dan R. Satriani. 2012. Strategi Pemasaran Keripik Pisang dalam rangka Mencapai Ketahanan Pangan di Kecamatan Cilongok, Kabupaten Banyumas. SEPA, 8(2): 162-167. 